\title{
Younger and Older Coastal Fishers Face Catastrophic Loss after Hurricane Katrina
}

\author{
Katie E. Cherry \\ Louisiana State University at Baton Rouge \\ Loren D. Marks \\ Brigham Young University - Provo, loren_marks@byu.edu \\ Rachel Adamek \\ Louisiana State University at Baton Rouge \\ Bethany A. Lyon \\ Louisiana State University at Baton Rouge
}

Follow this and additional works at: https://scholarsarchive.byu.edu/facpub

Part of the Other Social and Behavioral Sciences Commons

\section{Original Publication Citation}

Cherry, K., Marks, L., *Adamek, R., \& *Lyon, B.(2015). Younger and older coastal fishers face catastrophic loss after Hurricane Katrina. In K. Cherry (ed.), Traumatic stress and long-term recovery: Coping with disasters and other negative life events (pp. 327-348). New York: Springer.

\section{BYU ScholarsArchive Citation}

Cherry, Katie E.; Marks, Loren D.; Adamek, Rachel; and Lyon, Bethany A., "Younger and Older Coastal Fishers Face Catastrophic Loss after Hurricane Katrina" (2015). Faculty Publications. 4864.

https://scholarsarchive.byu.edu/facpub/4864

This Book Chapter is brought to you for free and open access by BYU ScholarsArchive. It has been accepted for inclusion in Faculty Publications by an authorized administrator of BYU ScholarsArchive. For more information, please contact ellen_amatangelo@byu.edu. 


\title{
Chapter 18 \\ Younger and Older Coastal Fishers Face Catastrophic Loss after Hurricane Katrina
}

\author{
Katie E. Cherry, Loren D. Marks, Rachel Adamek \\ and Bethany A. Lyon
}

\section{Introduction}

Natural disasters bring catastrophic destruction and traumatic stress. The psychosocial consequences of disasters include losses of material goods, property, and disruptions to social networks and lifestyle. Threats to mental health for survivors are an important public health consideration and may include post-traumatic stress disorder (PTSD), anxiety, and depression. These challenges, among others, are well documented in the disaster science literature in the first 2 years after a disaster (Cherry, 2009; Cherry, Galea, \& Silva, 2008; Neria, Galea, \& Norris, 2009). Comparatively less is known about long-term consequences for temporarily and permanently displaced residents of devastated communities more than 2 years after disaster (see Chaps. 10, 12, and 13, this volume).

The environmental consequences of hurricanes are of particular concern to commercial fishers for whom the water is a way of life. Coastal erosion and the progressive loss of barrier islands and marshland which have historically buffered the forceful impact of hurricanes are worrisome prospects. Louisiana's fishers produce a sizeable percentage of seafood worldwide and are recognized as the largest provider of seafood within the continental USA (Lee \& Blanchard, 2012). Despite their

\footnotetext{
K. E. Cherry $(\bowtie) \cdot$ R. Adamek $\cdot$ B. A. Lyon

Department of Psychology, Louisiana State University, 236 Audubon Hall,

Baton Rouge, LA 70803-5501, USA

e-mail: pskatie@1su.edu

R. Adamek

e-mail: rachel54a@gmail.com

B. A. Lyon

e-mail: blyon2@tigers.lsu.edu

L. D. Marks

School of Family Life, Brigham Young University, 2092C Joseph F. Smith Building,

Provo, Utah 84602, USA

e-mail: loren_marks@byu.edu

(C) Springer International Publishing Switzerland 2015

K. E. Cherry (ed.), Traumatic Stress and Long-Term Recovery,

DOI 10.1007/978-3-319-18866-9_18
} 
centrality to the seafood industry, relatively little research has addressed the impact of natural disasters on the US Gulf Coast commercial fishers, representing a serious gap in the disaster science literature. Because fishers' livelihood is dependent upon natural resources, one might expect greater risk for adverse psychological reactions after disaster compared to the general population. On the contrary, fishers' historical presence and longevity in hurricane-prone coastal regions imply a culture of resilience which may reduce vulnerability when treacherous hurricanes strike. Insights gained from commercial fishers and their families in the years after Katrina may shed new light on factors that lessen risk and promote resilience in the wake of catastrophic disaster.

On August 29, 2005, Hurricane Katrina made landfall in the US Gulf Coast region which includes (west to east) Texas, Louisiana, Mississippi, Alabama, and Florida. Katrina's swath of catastrophic destruction (declared a federal disaster area) was unusually wide, spanning an estimated 90,000 square miles, similar in size to Great Britain (Weisler, Barbee, \& Townsend, 2006). Many fishers in the present study had sheltered in place on boats secured in the Violet Canal and other ostensibly safe locations within the levee protection system. Large fishing vessels that did not sink in the storm became a collection point for storm victims rescued from roof tops or pulled from the flooding which followed the levee breaches in Katrina's immediate aftermath. An early coroner's report (September, 2005) offered a snapshot of the loss of human life, estimating that over a 1000 bodies were recovered from Katrina's floodwaters in New Orleans in the first weeks after the storm (Cataldie, 2007). Considered the most devastating and costly hurricane to hit the USA, Katrina's estimated death toll overall stands at 1,800 and over 125 billion US dollars in damages (Graumann et al., 2006). On September 24, 2005, less than a month after Katrina, Hurricane Rita crashed into the western side of Louisiana and southeast Texas. Rita, also a category 3 hurricane at landfall, directly caused seven fatalities and property damage reaching an estimated 11.3 billion US dollars (National Hurricane Center, 2007). For specifics on the 2005 hurricanes, see Cherry (2009), Kessler, Galea, Gruber, Sampson, Petukhova, and Wang (2009), and Kilmer, GilRivas, Tedeschi, and Calhoun (2010).

In this chapter, we focus on the commercial fishers of St. Bernard and Plaquemine Parishes. The rich cultural heritage of coastal fishers - lifestyles and traditions - and their intergenerational knowledge of hurricanes acquired over centuries of living in the bayous and natural waterways of south Louisiana warrant careful consideration. A glimpse of the history and cultural milieu that characterizes these south Louisiana fishing communities is given next.

\section{Historic Overview: Two Fishing Communities, Cultural Heritage, and Hurricanes}

Located approximately 5 miles southeast of the city of New Orleans, St. Bernard is a suburban community with an estimated pre-Katrina population of 68,000 . The population of St. Bernard is smaller today with current estimates at 43,482 
(US Census Bureau, 2013). Perhaps best known for its world-class seafood, St. Bernard is largely a fishing community and home to multigeneration families of fishers who have caught shrimp with nets on wooden boats ("double riggers") built with their own hands for over a century. A warm and personable community, St. Bernard also has a unique intergenerational aspect, where suburban families have grown up together as neighbors and friends for decades.

The longevity of fishing communities in St. Bernard is noteworthy, with a rich cultural heritage traced back to the 1780s when the first Isleños settlers from the Canary Islands came to south Louisiana. Spanish remains a predominant language spoken among some families of Isleños descent today (Coles, 2012). St. Bernard is also home to the Los Isleños Museum, which contains a treasure trove of Isleños' culture and folklore. Encapsulated in a quaint and historic wooden building (rebuilt in the years after Katrina) are ornate costumes and replicas of wooden fishing boats. Among the items on display are fascinating, although decidedly different home remedies for the treatment of a variety of maladies (Robin, 2000). The Isleño Fiesta, an annual festival sponsored by the Los Isleños Heritage and Cultural Society to celebrate Isleños' ways of life is held on the museum grounds in March (Los Isleños Learn, 2014).

Plaquemines Parish is another south Louisiana coastal community with a unique cultural heritage and is home to a multigenerational Croatian fishing community. As documented in Yugoslavs in Louisiana (Vujnovich, 1974), the first Croatian settlers came to south Louisiana in the 1800s and lived in camps on the bayous in Plaquemines, Jefferson, and Lafourche Parishes. Croatian men immigrated to south Louisiana and made their livelihood by oyster fishing, leaving their families, wives, and children in the old country. In the middle to late 1800s, the United Slavonian Benevolent Society (USBA) was formed. The USBA established tombs - one in Buras and one in the city of New Orleans - to allow proper burial for Croatian immigrants who died here (Ware, 1996).

Oyster farming is an important agricultural component in Plaquemines Parish, where residents have fished oysters on flat boats ("luggers") since the days of wooden rakes and backbreaking labor in the hot sun. Modern methods and mechanized dredging techniques are used to fish oysters today. In the 1950s, the Louisiana Oyster Dealers and Growers Association was formed to collectively lobby and promote the development of the oyster industry (Ware, 1996). Today, oyster farming remains a significant industry in Plaquemines Parish among other coastal parishes in south Louisiana, although the 2010 British Petroleum (BP) Deepwater Horizon Oil Spill has severely threatened this industry, as discussed in Chap. 4 (this volume).

In addition to the Croatian community and oyster farming, Plaquemines Parish is significant as the site where Hurricane Katrina made landfall. Packing $150 \mathrm{mph}$ winds, the eye of Hurricane Katrina covered a 30-50-mile swath, from Buras to Pointe a la Hache (see Fig. 18.1). The levee surrounding this part of south Louisiana was not breached; it was overtopped, bringing a devastating 30-40 ft of water into south Plaquemines. With unrelenting force, this water punched a hole on the other side, a levee breach from the inside out, leaving a gaping $150-\mathrm{ft}$ hole straight into 


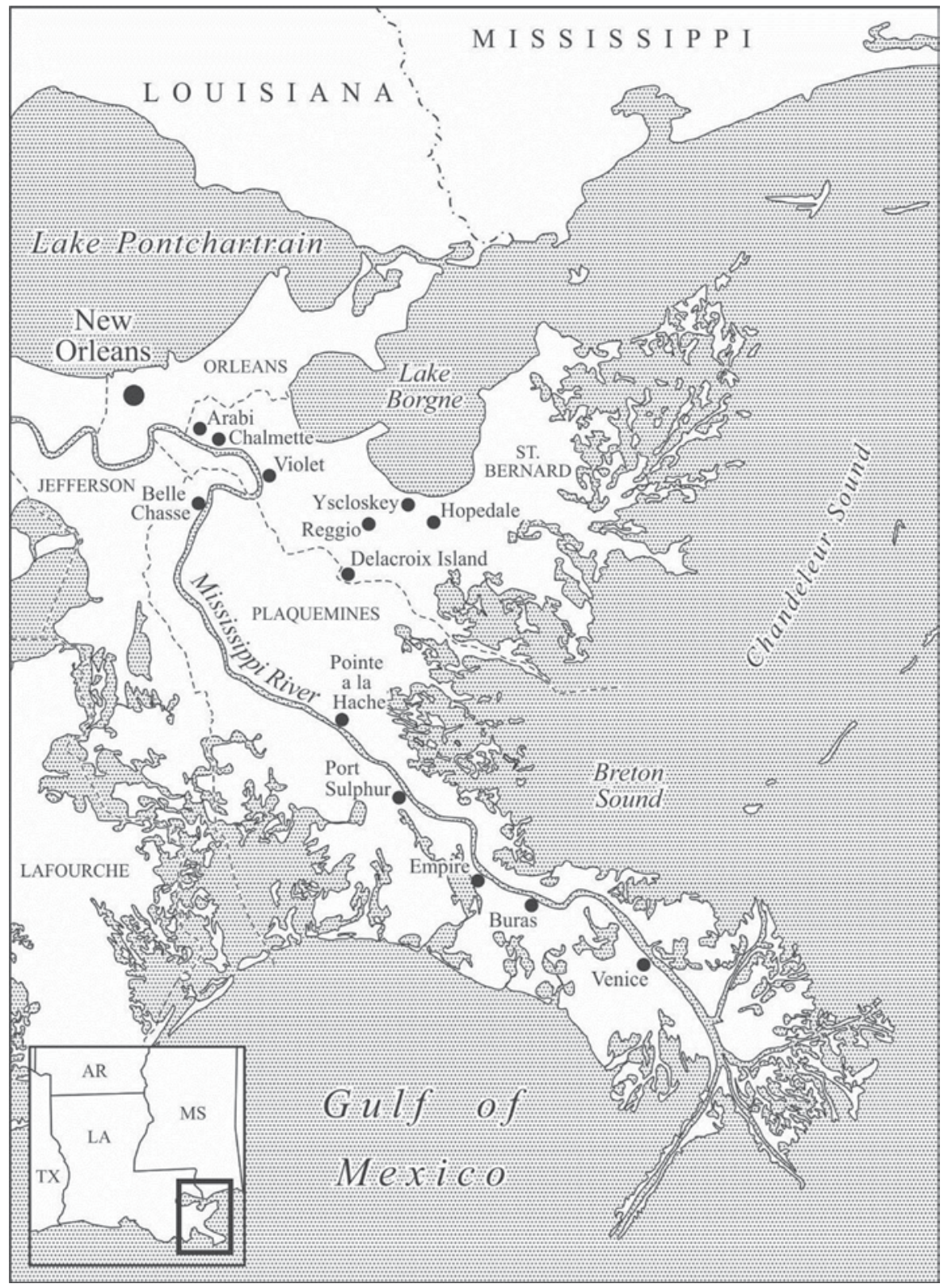

Fig. 18.1 St. Bernard and Plaquemines Parishes in South Louisiana. (Courtesy of Mary Lee Eggart, Cartographer, 2014)

the Gulf of Mexico. As the first author has been told by a resident of Buras who witnessed Katrina's aftermath, the flooded towns in south Plaquemines experienced a tide, bringing all manner of sea life from the Gulf directly into people's front yards. 
Lifelong residents of the US Gulf Coast are well acquainted with the threat and environmental realities of severe weather. The Atlantic hurricane season begins on June 1 and concludes on November 30 (National Hurricane Center, 2015). Year after year, hurricane season comes and goes, sometimes with great activity churning in the Gulf of Mexico and other times with less activity and relative calm. Storm preparations and anticipation are fundamental to coastal residents. They either evacuate, leaving the area for a few days until the storm has passed, or they hunker down and ride out the storm as coastal residents have done for centuries. For commercial fishers, the large shrimping and oyster boats are moved to secure locations within the levee protection system or taken to distant ports well beyond the anticipated reach of a potentially deadly hurricane. No one would have imagined these austere and commanding sea vessels would become a safe haven for hundreds of storm-ravaged strangers rescued by first responders and brave citizens in the last days of August 2005.

For younger and older coastal residents alike, storms associated with flooding and significant property damage stand out in memory, serving as a reference point against which future storms are compared. Older coastal residents talk about hurricanes that destroyed homes before storms were named. For example, the unnamed storm of 1947 demolished homes in Yscloskey, Hopedale, and Delacroix Island (see Fig. 18.1). Less than a decade later, Hurricane Flossy struck the central Gulf Coast on September 24, 1956, as a category 1 storm that directly caused 15 deaths (Dunn, Davis, \& Moore, 1956). Middle-aged and older coastal residents spoke of Hurricane Betsy on September 9, 1965, with flooding in New Orleans and portions of St. Bernard. At 90 years of age, one lifelong coastal resident spoke of losing homes in three different hurricanes, Flossy, Betsy, and Katrina. As she described it, rebuilding homes and reestablishing routines of everyday living were part of life, something one does without hesitation or complaint. Listening to very old adults describe losing everything and rebuilding multiple times without litany, self-pity, or blame, one gets the sense that resilience (referring to the tendency to bounce back from negative life events) is a developmental characteristic acquired over time through experience and repeated exposure to adversity.

To summarize, we explore Katrina's impact on commercial fishers and their family members who depend on natural resources for their livelihood in this chapter. The contrast between younger (less than 55 years of age) and older ( $55+$ years) fishers is of particular interest. One might reasonably assume that distal variables such as cultural heritage and tradition may hold greater meaning among older fishers. Older fishers who have lived in hurricane-prone coastal regions for over a halfcentury have likely developed hurricane preparedness techniques and methods of coping, possibly passed down through fishing families for generations. These personal characteristics among seasoned fishers may contribute to individual and family resilience and the recovery and revitalization of communities when deadly and destructive hurricanes strike. 


\section{Method}

\section{Participants and Procedure}

The sample was comprised of 64 fishers and their family members. All had experienced catastrophic losses in the 2005 hurricanes (Cherry et al., 2015; Chap. 4, this volume). To examine age-related differences in coping responses, the sample was split at the median age to form groups of younger $(M=43.2, \mathrm{SD}=10.9$ years; age range: $21-54$ years $)$ and older adults $(M=66.5, \mathrm{SD}=10.5$ years; age range: $55-90$ years). In this chapter, we focus on fishers' responses to the following open-ended questions:

1. In times of trouble, people often turn to their religion and spiritual beliefs to help them cope with life stresses. Have your religious beliefs and practices helped you cope with Hurricanes Katrina and Rita? If so, in what way?

2. In times of trouble, people may turn to a faith community to help them cope with life stresses. Has a church or faith community helped you cope with Hurricanes Katrina and Rita? If so, in what way?

3. They say every cloud has a silver lining, and even the most awful events can have positive outcomes. Do you think there are any positive outcomes that can come from Hurricanes Katrina and Rita? If so, what are they?

Of the 64 persons in the sample, four couples responded jointly to the open-ended questions, and one participant declined for a total of 59 responses which were digitally recorded and transcribed verbatim. For each transcription, two separate data audits were performed by different graduate research assistants to ensure accuracy of these narrative data.

\section{Analyses and Coding}

Narrative data were content analyzed in a manner consistent with grounded theory methodology (Strauss \& Corbin, 1998). Two student teams (each comprised of four coders and one team leader) met weekly during the 2014 spring semester to carry out the open-coding process (see Chap. 12, this volume, for a description). One team coded younger fishers' responses, and the other team coded older fishers' responses. Each week, the two coding teams met separately to discuss the prevalent ideas and themes covered in the interviews. To ensure that all reported themes for the two age groups were verifiable and clearly supported by the data, the two team leaders revisited all interviews within their age group and copied and pasted primary data that had been directly linked with major themes. As a final check to increase rigor, two senior research assistants who had not participated in the opencoding process reviewed the data files (one file for each major theme) for accuracy and completeness. As a result, each of the major themes reported here had several pages of supporting data drawn from multiple interviews - consistent with Patton's (2002) recommendation of creating a data "audit trail" (p. 93). 
For the major themes identified in this chapter, there was some overlap and similarity across the two age groups. There were, however, differences in the respective order of importance and salience across age groups - as well as some nuances that were captured during the process of team-based analysis. These themes are reported next along with more than 50 illustrative and supportive examples taken directly from the interviews.

\section{Findings}

In overview, we begin with Materialism and True Colors Revealed: Despicable Deeds and Acts of Grace After the Storm (Theme 1). In this theme, we focus on the polarizing effects of Katrina, where the best and the worst of humanity seemed evident after the storm. The next theme, Helping Efforts Across Denominations (Theme 2), overlaps substantially across the younger and older groups. Participants in both age groups revealed similar (sometimes strikingly similar) perceptions and reports in connection with this theme. However, our last theme, Historical Ties that Bind: Old Roots Versus New Connections (Theme 3), features noteworthy differences in responses between younger and older coastal fishers.

\section{Theme 1: Materialism and True Colors Revealed: Despicable Deeds and Acts of Grace After the Storm}

The first central theme voiced by our participants reflects a recurring, heightened awareness of the fleeting nature of material possessions. Many participants critically discussed some aspect of what might be broadly labeled materialism. With respect to money and the material possessions that money can buy, the catastrophic Hurricanes, Katrina and Rita, seemed to yield or "reveal" two diametrically opposed patterns of human response. One end of the spectrum involves the phenomena of looting and corruptly maximizing profits - the other end is an elevated sense of the worth of human life, often accompanied by generosity and unselfishness. In connection with Theme 1, we begin with a few brief references to the negative tendencies witnessed in Katrina's aftermath (see also Chap. 13, this volume).

One participant noted that several of the "kids" that lived around him started looting after the storm. He reportedly redirected their efforts:

361: They were coming back with TVs. They were stealing everything, you know. Radios, and TVs, and stuff like that...the kids [were]. I said, "But listen: Where you going to go with that? You can't eat it, and you can't drink it! You [are] going to starve to death with that! ...Come back with food! ....You see anything floating [that we can eat], don't be stupid, pick it up, the canned goods, pick them up! Go gather food! And you all come right back here." So, boy, they go gather up [canned food] stuff and they come right back to me. And then I formed a posse, the kids got together, it was the kids that did everything [to keep us alive]. (O)(57-year-old male) 
As looting of possessions reached its peak and began to spill from businesses to homes, the concerns of non-evacuated survivors spiked. One participant recalled:

334: “[At first] I left the gun out. [But then], I couldn't. I said, "What do I need a gun for?

We don't need a gun, we just got hit with a hurricane." $(O)$ (58-year-old female)

A few participants shared their view that the aftermath of the hurricane(s) revealed the "true identity" or "true colors" of people. The following excerpt is illustrative:

352: People were brought to their bare self. People... their true identity had become exposed. [You saw them] for what they really were.... You're at the mercy of whoever will show you any [mercy].... But [some] people used and manipulated and lied and took advantage and abused [other people] on a scale that was-[well], it was despicable. And [some who did these things] showed no remorse, or respect for people because they felt [that others] owe them something, I guess. (Y)(46-year-old male)

Another woman (312) similarly concluded that the changes and financial upheaval surrounding the hurricanes created a context where "We got to see true colors of people." (Y)(40-year-old female). While some storm survivors were eager to grab and acquire during the aftermath, first responders and other heroic citizens who had not evacuated before the storm were concerned with saving lives (for documentary evidence and specific description, see Buuck, 2007; Schaefer, 2007; Wells, 2008). A college-aged participant, who spoke of his mother (who was accustomed to providing for herself), provides a striking counter example to looting and stealing to improve one's own lot. He recalled:

314: We didn't have anything to eat, and the Red Cross would come around giving out lunches and my mom was crying because she didn't want to have to take food.... (Y) (22-year-old male)

The same young man, who was in high school at the time Katrina hit, also recalled:

314: [The] environment at Holy Cross [School] helped me be strong through times like that, and you see other kids at school and they're dealing with the same problems that you're dealing with. I know some kids that didn't have that strong family behind them like I did. I was...like I said, I was blessed to have that.... I know this one...guy I went to school with...he was working two jobs to help his mom rebuild their house [and he was still] in high school. I mean who should have to do that?

The crisis of Katrina placed new demands but also reportedly stimulated new opportunities and realizations in the lives of many of our participants.

As noted earlier, there were some reports and witnesses relating to persons who seemed to emphasize and cling to the monetary and material aspects of life through looting, dishonest manipulation, and other antisocial channels. Although this tendency to "grab" was mentioned, participants' reports far more frequently referenced changes away from a materialistic or acquisition orientation in their own lives (see Chap. 21, this volume). The remainder of this theme's discussion is devoted to conveying the participants' related experiences and differences in the outlook on life they reported. Some, for example, juxtaposed the fleeting value of possessions with the precious nature of life itself, as reflected in these five excerpts:

302: The one positive thing I could think of is that we're all living, we still, all my family made it through the storm; [our pets and] animals, and all my friends that I know made it 
through the storm. And you know, the possessions, you can always get back... [But] life you can't. ...I want to take every day... like it's the last day. (O)(59-year-old male)

346: [The initial shock] goes beyond just losing your home and pictures and your belongings. [What really makes you] emotionally distraught...[is] not knowing if your family members are okay and where you're going to end up next or what's going to happen [in] your future [life]. (Y)(25-year-old female)

339: [Y]ou got your babies, that's the main thing. You can replace things, but you can't replace a life. $(O)(63$-year-old female)

313: As long as it is not a human life and it is material things [that you lost], they can be replaced, and [things] are not really worth what you think they are anyway. (Y)(47-year-old male)

345: I hear...after Katrina, with [our] loss[es], "I'm so sorry” and I'm like, “Don't be. You know [what, our stuff might be gone but], we're still alive. (Y)(51-year-old male)

Several participants reportedly experienced a change in priorities following Katrina - a change away from an acquisition orientation or what finance scholars refer to as "conspicuous consumption" (Moore \& Asay, 2008). The following excerpts are representative of a larger array of similar responses:

341: [I realized that] when I go out [of this life], I got to give [my stuff] to somebody else. But I done got that figured out. A lot of people are still trying to acquire things. I've done switched that off. I don't need to acquire no more things. And I find that's what makes living life a lot better, when you [see that you] only need so many things. When you get too overwhelmed with acquiring things, it messes your life up. (O)(55-year-old male)

Participant 341 mentioned that when this life is over, he will have to "give [his stuff] to somebody else." However, the next participant decided not to wait that long before passing along much of her wardrobe. She explained:

331: My biggest thing that I think everyone should know is not to take anything for granted. It's, because that's how I was before Katrina. I just figured that's how it was for everybody; and now I don't take anything for granted at all....That's the biggest thing that I learned from Katrina. And [I learned that] material possessions don't mean anything.... I have so many clothes, I'm giving them all away... [I was really down after Katrina but my friend], she told me one day that I had to get a grip and stop complaining and fix myself in my head. So, I just, I don't know, something just clicked. I just decided to go [and do things differently]... I kind of made "before-Katrina" life seem more like it was a different life, [that person was] not me. That was somebody else who lived that [way], that's kind of how I see it now.... (Y)(21-year-old female)

\section{Two other shifts in perspective follow next:}

330: The acts of kindness [from others], that is what was the silver lining. We really relearned what was really important. You know, before the storm we had a lot of material things and the kids were both in private schools. We were working really hard to supply the kids with a life that we thought was a good life for them. And after we went through everything, what we thought was good did not mean that much. And we had to go through [Katrina] to find [that] out.... And hopefully by us seeing it that way, the girls will live a life... [that is] more rewarding. (Y)(43-year-old female)

324: [An experience like Katrina] reminds us that...the material things in this life are really not that important because no matter how much you have, [no matter how many goods you] accumulate here, you're going to lose them sooner or later-whether you lose them in a 
disaster or...[well], if you don't lose them that way, you're going to lose them when you die anyway.... [Really remembering] that makes us realize [that] what's really important in life is your relationship with your friends and family and God. (O)(55-year-old female)

The latter reflection from participant 324 presents not only a reminder or remembrance that "the material things in this life are really not that important" but also an emphasis that what is "really important in life is your relationship with your friends and family and God." Several of the participants not only mentioned a personal or familial move away from materialism following Katrina - they also invoked the Divine in their discussion, as captured in the following two examples:

325: [God] helped me. The thing is that it is not about...material things, [material things] are not everything, you know. (O)(60-year-old male)

332: [Y] ou can show a young person that in spite of the devastation we had down here, we still had God. We still had family. We still had church. Despite losing everything [possession wise]...that [faith] was there, so we never really lost everything. (Y)(52-year-old female)

A final illustration of both a shift away from materialism and an invocation of God came from an individual who referenced significant financial resources and mentioned that they do not have "bills [they] can't pay." However, this participant framed the life-altering catastrophe of Katrina as something that reportedly awoke him and gave him "my soul back." He explained:

\begin{abstract}
352: God took me out of my element because He knew that I had no chance of changing my life from what I was, in my surroundings. I had no chance of making it [spiritually, the way I was].... There is a whole lot of worse things that could have happened to me. I feel quite blessed, very fortunate. I left. I saved not only my life, but gained a soul. I gained my soul back. I got my life. God gave me a new life... greater than any life I have ever had up to that point.... Who would you call upon to help you if not Him when you need it the most? People can only give you information or money. Maybe that is what you need sometimes, but it never seems to fill the void. You are always missing something.... I have lost everything behind me, and I have gained everything in front of me.... (Y)(46-year-old male)
\end{abstract}

For many of our participants, life after Katrina was never the same. However, in some cases, life was not only more challenging but also spiritually and relationally richer - sparked by a renewed emphasis on precious intangibles such as faith, true friendship, and family relationships. It is to these intangibles that we now turn.

\title{
Theme 2-Helping Efforts Across Denominations: “[God] was using His people to help His [other] people."
}

A discussion of religious denominational differences in Louisiana requires a brief note on social and religious historical context. Based on data from the US Census Bureau, the 2013 population of Louisiana was a little over 4.6 million. The largest denomination in the state is the Catholic Church with more than 1.2 million adherents followed by the Southern Baptist Convention with 709,650 members. No 
other faith exceeds 200,000 members (Louisiana Religion Traditions, 2010), making Louisiana a predominantly Catholic/Baptist state.

In terms of religious heritage, French Catholic settlers in Nova Scotia (called Acadians or "Cajuns") engaged in a series of battles with British troops during the early and middle eighteenth century that climaxed during the French and Indian War. Commencing in 1755, thousands of Acadians were expelled from Nova Scotia, and many of these refugees settled in regions that comprise present-day south Louisiana (Faragher, 2005). This "tragic...expulsion of the French [Catholic] Acadians" from Nova Scotia by the armed forces representing England and her Protestant faith laid a foundation for deep-seated tensions between Catholics and Protestants in Louisiana (Faragher, 2005). At least remnants of these tensions are apparent two and a half centuries later-indeed, the state remains divided into a northern, Baptist "Bible belt," and the heavily Catholic and Acadian ("Cajun") southern portion of the state that depends largely on the mouth of the Mississippi River and the waters of the Gulf of Mexico for economic and literal sustenance.

Consistent with this religious and demographic sketch, the Louisiana Gulf Coast fishing families interviewed during the present research project were predominantly Catholic (73.4\%). This context sets the table for our second emergent theme, which addresses significant reported and perceived differences in helping, rescuing, and assistance efforts made by churches and church members in the aftermath of both natural (Hurricanes Katrina and Rita) and man-made (Deepwater Horizon Oil Spill) disasters. As one participant summarized:

326: It just makes you realize that, you know, in times of trouble, you know, you will have somebody there to help you. (Y)(52-year-old male)

One young woman was sufficiently impressed by the "on-the-ground" disaster recovery efforts of diverse churches that she made an effort to attend and worship with some of them. After Katrina hit, she reported:

331: I would come home and read my Bible and pray. I think without all those different groups of churches [that helped out], I don't think I would've been able to cope as well as I did. Because I got something from each different church that I went to; I got a different little view on everything. (Y)(21-year-old female)

Another woman was also impressed by the array of engaged churches that she witnessed in action in the aftermath. She said of the churches,

318: They all wanted to help. And I think that in helping others, you feel like you have done something worthwhile. (Y)(50-year-old female)

A man reflected in his interview on his astonishment at diverse church involvement in the disaster aftermath. He admitted,

304: That was kind of surprising to me, I ain't going to lie. I was [blown away]. All of them people, [all of them] different religions, and they're all helping, you know? But they did. And like I said, it wasn't just one religion, it was all of them, you know? (Y)(46-year-old male) 
From among the many denominations that helped, some participants singled out a specific group that impressed them. When talking about helpful faith community involvement, this woman told us:

332: Yes, [I remember] the Amish. And some of those men would just show up. We're not of the Amish faith and don't care to participate in the Amish faith, but it was another demonstration of the community of churches setting aside their philosophical differences to deal with the truly [incredible] physical devastation down here. Those men would come down here with hammers and shovels and whatever they needed... and help as much as they were able. And they didn't preach to you, but you got to see how they lived.... [T] he Amish guys were helping clean up around here, helping people hammer things back together or reconstruct from nothing. And the wives would be right behind them making sure that you had clean clothes, you had food. ...[They] would take your children and just go play with your children so the grown-ups could do grown-up things without having to stress about the kids.... It reaffirms your faith in the compassion of man.... And they never forced their faith on you, but if you were willing to share God, they were willing to listen. So, I think that's pretty big. (Y)(52-year-old female)

Another man related his experience with a work group from a church whose name he did not mention and may not have even been aware of - although it was apparently not "their" church.

345: They were a church group [and they were] going to gut ${ }^{1}$ this person's house out...[but] he changed his mind. So they had nothing to do so they all came down my way.... And I said, "Well, [I can sure use your help]." We knocked it out in an hour and a half. So that was a great blessing. And somebody happened to call and I said, "God sent me about twenty angels here. I'll be wrapped up this evening!" So that was really, really good. And they felt good about what they did. For a person who doesn't really like to ask for help, like myself, it was a real blessing.... God wrapped it up. (Y)(51-year-old male)

Even among our predominantly Catholic sample, several positive comments were made about the outreach efforts of the Baptist church, including the following report:

331: [One group that helped us was] the Baptist church, everything that they did for us. They showed me that we weren't alone. And that also helped me see that even though we had our house destroyed and everything destroyed, we weren't...God didn't abandon us completely. (Y)(21-year-old female)

Another Catholic participant recalled another kind "gesture" from members of the Baptist church that boosted her faith:

353: [A group that] was from a Baptist church, just came along and gave everybody ten dollars, and it was just so... it was a wonderful gesture. [M]y son said, "What's ten dollars?" I said, "It's not the ten dollars, it's the idea that these people came out to help." And I think that, that made you even have more faith in God, because He was using His people to help His [other] people. (O)(71-year-old female)

\footnotetext{
${ }^{1}$ When floods strike, a top priority in home cleanup is to remove soaked sheetrock and insulation to prevent the base of the lumber framing from rot. This urgent removal is referred to as "gutting." If gutting is done soon after the flooding, it can prevent rot from destroying the structural integrity of the home. If gutting is delayed and rot commences, the entire home must be razed. During hurricane aftermath, some church groups like the one referenced here go out in clean-up parties to do this urgently needed work without compensation.
} 
The implicit use of language by this participant to indicate that both Baptists and Catholics are "His (God's) people" is representative of a post-disaster outreach of warmth and brotherhood that seemed to be present in several interviews. However, while goodwill for "His people" from Protestant denominations was apparent in several interviews with Catholic participants, another (not overpowering but discernible) theme was a recurring frustration with the Catholic Church's less than adequate outreach, as reported by some long-time Catholic parishioners (see Chap. 14, this volume). One man who had lost his home and business in Katrina went to Mass in a different state during his evacuation. He told us:

303: I just can't believe it either. I was standing there, I was shocked. I was standing there when [the priest at the church] says, "Well, if you're looking for a hand out, I can't help you. We lost the roof off our church and we need five thousand dollars to repair our roof." (Y)(42-year-old male)

Another participant reported a very similar experience with her sister when they visited a church during their evacuation shortly after Katrina. She reported the following interaction with a church representative:

312: [The] exact words to my sister - I turned around and walked away- [were], "We don't have anything for you." And my sister said, "I just want to go to Church services." He says, "Well, if you want to come to a service that's fine, but we don't have anything for you." (Y) (40-year-old female)

Our intent here is not to malign any church, including the Catholic Church. ${ }^{2}$ Examples like the previous one recurred, but there were other Catholic participants who noted and applauded the efforts of specific Catholic churches in the area. For example, Participant 318 reported, "The Immaculate Heart of Mary is the church that my brother goes to.... They collected $\$ 25,000 \ldots$ in one weekend for Katrina [victims]." (Y)(50-year-old male).

In Chap. 14 (this volume), we discuss the complexities and challenges of the Catholic Church's response in the Katrina aftermath in greater detail. However, the following excerpt fleshes out (and adds needed balance to) our brief discussion here: One of the cruelest consequences of the storms for our participants who were heavily invested in faith community was that those neighborhoods who suffered the most severe damage to homes were the same neighborhoods most likely to lose their (heavily damaged) neighborhood churches. Thus, those who arguably needed their own faith community, their own priest, (and) their own familiar sacred building most profoundly were least likely to have access to these spiritual and physical resources. As a 77-year-old female from our parallel study summarized:

215: When I came back here [after the flooding], everything was so disorganized...the church was suffering the same way we all were. The church lost everything too. Remember? The rectory, the church was flooded. Everything [was flooded]. The church was in dire

\footnotetext{
${ }^{2}$ The authors have published several previous articles or chapters containing largely or partly Catholic samples that present the faith from a constructive perspective, based on participants' reports. Indeed, one such article has focused solely on the strengths of Roman Catholic families (Batson \& Marks, 2008).
} 
need of help itself. I mean as far as the community goes...basically, there was hardly any community. Everybody was in the same boat. Everybody...that came back was rebuilding their houses, rebuilding their lives. The church was trying to rebuild. The church lost everything $[$ too $] .. .$.

The recurring negative reports and perceptions regarding Catholic-based outreach (or lack of Catholic outreach) by the Catholic participants... and the recurring positive reports of the helping efforts of non-Catholic denominations are somewhat counterintuitive - based on documented trends in psychological research indicating that participants tend to rate the efforts and performance of groups to which one belongs more favorably (Roese \& Olson, 2007).

In Theme 2 (Helping Efforts Across Denominations), we have discussed the participant-lauded relief efforts of "outside" churches during the Katrina/Rita aftermath. These churches were often "outside" in two respects: (1) The faith-based groups were typically non-Catholic and (2) the groups were often from other cities, geographical areas, or even other states. Some groups stayed for days or even weeks - but eventually they had to return to their homes. As time progressed and infrastructure returned, the local or "insider" churches reportedly regained traction and influence. Indeed, support from "their" local faith communities was frequently referenced as participants learned how to live again during the longterm recovery.

As we conclude our discussions of Themes 1 and 2, we remind the reader that there were minimal age-related differences between the younger $(<55$ years) and older (55+years) groups with these themes. Indeed, the content of participants' responses was very similar. In the third and final theme, however, age group differences did emerge, and we saw discernible markers based on longevity and life experience, as discussed next.

\section{Theme 3: Historical Ties that Bind: Old Roots Versus New Connections}

Katrina's massive storm surge left no home or building standing; only tangled marsh grass and thick mud so deep that it was difficult to discern where one's property began. News media and press reports at the time document the destruction of coastal towns in St. Bernard and Plaquemines Parishes. In fact, the Chicago Tribune ran a story detailing the devastation of Reggio, Yscloskey, and Hopedale, noting that these small towns of eastern St. Bernard were seemingly wiped off of the map (see Fig. 18.1; Janega, 2005). Coastal residents without habitable dwellings or knowledge of whether services (electricity and gas) would be restored to these outlying areas were displaced for months - and up to 2 years or more for some.

Both younger and older fishers spoke of feeling unwelcomed and out of place in the communities to which they had evacuated (see also Chaps. 12 and 13, this volume). One younger participant (318) reported that after the mass evacuation and relocation, a woman in the community she had relocated to was lamenting on the 
influx and speaking in a derogatory way about the Chalmette evacuees in particular. This participant's loved one reportedly objected, spoke up, and said:

"I am from Chalmette." [Then the woman], she says, "You and all the people from Chalmette, I wish all of you would go back."

Participant 318 went on to share her perception that:

I guess it is the stress of having so many people move into your community. All of a sudden it is a population explosion [with so many people moving]... from one area to another. (Y) (50-year-old female)

Another participant (331), a high school student at the time, recalled that to the young people in the city where she and her family temporarily relocated, "I was the 'Katrina girl' from New Orleans who talked funny..." (Y) (21-year-old female).

Reports of "insider/outsider" perspective were not limited to fishers who temporarily resided in distant cities. In the eyes of some persons who went back to their coastal communities, the storms had a "cleansing" effect on the population, in that only those who deeply wanted to be there to rebuild returned. An older fisher related his views with blatant disdain for nefarious "opportunists" seeking to maximize personal gain at the expense of others, as follows:

341: [A]fter the storm, we had a lot of people in this parish that I would say that were undesirable... "trash." I hate to say that word. I try not to be a mean person. But they weren't born here, they just come [in] here... [Some of them were] opportunists and living and getting whatever they could get off of nothing. So the true people that wanted to stay here, that were born and raised here, stood. And the undesirables and the people that were just opportunists think they can just try and make hustles - well, they're gone. We got rid of them. So it basically cleaned, it cleansed the parish. (O)(55-year-old male)

In participant 341 's remark, one can sense the depth of affinity and respect for his ancestral homeland, despite Katrina's devastation. Scholars use the term place attachment to describe the strong emotional bond that draws people to particular geographic areas that they consider "home." Affectionately known as "da parish," lifelong residents of eastern St. Bernard voiced concerns not only about the social environment but also about the insidious effects of coastal erosion, loss of marshland and barrier islands, and the long-term viability of the bayous and natural waterways of south Louisiana. Environmental concerns were both frequent and salient among the older fishers. Indeed, this was the sharpest point of contrast with the younger fishers who more often spoke of new social opportunities and forming lasting friendships with their displacement hosts in distant communities, as discussed more fully next.

Regarding new social ties, younger and older participants spoke with appreciation and gratitude toward those who had warmly welcomed them in host communities in neighboring states, including (but not limited to): Texas, Mississippi, Alabama, Georgia, Tennessee, and Florida. Organized relief efforts carried out by volunteers associated with faith-based groups made a tremendous difference, providing material goods and assistance with finding suitable housing for displaced fishers for the long months away from their ruined coastal homes. Many in the younger age group spoke of new connections and social relationships they had established 
with their displacement hosts. Some reportedly still keep in touch with their former hosts in other states. A counterpoint to the "insider/ outsider" mentality so many participants referenced, the kindness of strangers who warmly welcomed displaced fishers and provided for their material needs sometimes led to the formation of meaningful relationships that, in certain cases, continue today. The silver lining of new friendships and social ties was a frequent and salient trend coded in the primary data that was almost exclusively confined to those in the younger age group.

For those in the older age group, historical ties to multigenerational fishing communities and a deeply rooted cultural identity were frequent and salient in the primary data. A key factor was fishing - not only as a livelihood but also as a culture, an identity, a Gulf Coast-based society, and a "lifestyle" (see also, Wells, 2008). The following narratives capture and reflect a portion of the post-Katrina and postDeepwater Horizon oil spill sense of the irretrievable loss of something more than boats, equipment, and fish — a loss disproportionately felt by the older group or participants. Commenting on what she missed most, one woman from the older group told us:

323: It was the lifestyle. It wasn't that my stuff was gone. I can deal with that. It was that you knew from this moment on, your life is never going to be the same. The people you've met, a lot of them you've been raised with...you might not ever see these people again in your life because they're gone from sight. You know?...And then, the [loss of the fishing] livelihood to people. Everything was disrupted.... That's what I was stressing over, not things. It was people. You see? And that was the hard part. (O)(57-year-old female)

The same participant (323) continued, "When I [re]-did the house, I thought of the possessions and stuff...[and I was able to] let it go, you know?" But for her, and many others, the fading out of a way of life — a fishing life — was a difficult and deeply painful prospect.

Another older fisher seemed to summarize in four brief sentences the essence of what many others struggled to convey, namely, that fishing was not just something they did - it was a large part of who they were:

341: Yeah, I am a fisherman. You can put me in my boat and if I got two bottles of water and cooking oil and a fire and a dozen oysters, [then] I am good for a week. The majority of people I was raised with, that's how we are. We just we don't need a lot. (O)(55-year-old male)

Like other folks in the fishing communities of south Louisiana, including the previous wife and mother (323) who was able to "let [her 'stuff'] go," participant 341 minimizes the importance of possessions ("We just don't need a lot"). However, the same centrality of fishing to life and identity seems to emanate from his brief, but clear statement.

Another participant, who was very young (22 years), showed a "stay and fight" persona reminiscent of many of the seasoned older fishers:

314: You know, people thought it was the end of the world, but I mean, if another Katrina came tomorrow, I would still be back here a couple of days later trying to rebuild. ...Like my house. I worked hard to rebuild it, but like I said, if Katrina came tomorrow, I would be back fixing it. You just roll with the punches. Like I said last time, you can't cry over spilled milk. You [are] just going to have to deal with it and clean it up and get another glass.... It's not that big of a deal. It's just who I am. You just have to kind of roll with the punches; you 
just learn to deal with stuff... I kept my head up, and I didn't want people to feel sorry for me, I just did what I had to do. (Y)(22-year-old male)

If this young man's reflections convey some bravado, perhaps a high-held chin is well earned by one who absorbed several disastrous "punches" and still remained on his proverbial feet. This young man also showed a softer side. Discussing benefits of what he experienced, he said:

314: What matters is your family and, at least to me, I know one thing positive that came out of it for me was I learned how much my family really means to me.

Another participant from our younger group of fishers chose to frame Katrina in ways that emphasized two "good" outcomes of the tragedy. She said:

316: Well, for one, it [the storm] gave people a lot of knowledge that they can do it-that they do have the will power to do it. You just have to stick with it.... [T]here's no problems, there's only challenges... [Another thing that was] good about the storm, it did umm... it didn't discriminate. It affected everybody, whether you were rich, poor, black, white... it just didn't matter. It didn't matter where you lived. Mm-hmm, yes, [it hurt us all] which united us all. We have a common...goal. [It] was to rebuild and to get back on with our life. (Y)(51-year-old female)

Importantly, "good" outcomes that came about after Katrina were not limited to younger fishers. New opportunities for cultural identity and growth in Plaquemines Parish, reflecting a deeply rooted Croatian heritage of hard work, perseverance, and love of family and friends (Ware, 2013), can be seen in this narrative from an older Croatian couple:

324: So...the positive outcome is that we do treasure our relationships with our, with our family and friends even more. And then, like last week, I thought about, some of our Croatian friends are closer now. They, some lived in Chalmette area, they lost their homes so they moved to Belle Chasse. Other people were like us in lower Plaquemines that ended up moving here so, the Croatian community has become a little more... (O)(55-year-old wife)

\section{5: Close together $(O)(60$-year-old husband).}

324: [Yes] more clustered. And, we've been able to, we're starting our own Croatian [cultural center]. We've got a piece of property [two and a half acres in Jesuit Bend donated after the storm], we're building a center. We're redoing a little building into a [community] center and I think that would have been a lot harder...harder to come by if it wasn't for Katrina and Rita.

The older group seemed to report strong community ties and stronger ties to the "way of life" more often than their younger counterparts did, although overgeneralization should be avoided. As we see with participants 314 and 316, there were some younger fishers who were highly invested in literally and socially restoring hurricane-devastated communities. Further, there were some in the older group who seemed to have absorbed one blow too many and were preparing to try a life in a less perilous locale. One married couple with strong family ties to the oyster industry shared these sentiments just weeks after Hurricane Isaac swept through south Louisiana on the seventh Katrina anniversary (August 29, 2012):

359/360: No, we know we are not secure. And, you know, with [Hurricane] Isaac it just... reinforces that.... Yes, you do what you can and you fight and all, but then you realize this is not something that we have to endure. We do not have to live here, and we decided to 
live here by choice after the hurricane. We did not leave, but if you keep getting hit on the head, you know, I do not think we plan on staying here. I really do not. (Y)(359, 52-year-old female; 360, 55-year old male)

We conclude our discussion of Theme 3 with several excerpts from both younger and older fishers, which seemed to illustrate convergence of thinking - that the storms taught the lesson that historical ties with deep roots to one's cultural heritage and traditions, especially family relationships, are the "irreplaceable core" of life.

334/361: [The experience with the storms] brought people together. It made you realize just how close...your family is, and how much they mean to you. It brought a lot of families together.... It did. ...My family's more important to me than anything. $(O)(334,58$-yearold female; 361, 57-year-old male)

346: [One silver lining through all of this is] the quality time spent with family. (Y)(25-yearold female)

332: I know everybody in my family is only a phone call away, and if I say, "We've got to pray," then that's what we do. We stop right there. Don't even ask what's going on. Don't worry about what the problem is. Let's just pray, and God gives us the strength, and God gives us the...family camaraderie to get through it. (Y)(52-year-old female)

For many, the vital support of (and closeness with) family during "times of trouble" was a treasure pulled from the muck of the disasters. While the preceding three narratives specifically identify "family" as a coping support, other participants also referenced important assistance more generally_from "people" who were "there to help."

332: So many things had happened in a negative way since 9/11 [in 2001] that you begin to doubt, and you begin to be nervous about people's motives; and then post-Katrina, postRita, people's motives were simply to hold you up or lift you up or drag you up by your boot straps, depending on what you needed.... as long as you weren't just sitting there with a hand out, these people were there to give you a hand up..... learned how truly loved we were and continue to be. (Y)(52-year-old female)

326: It just makes you realize that, you know, in times of trouble...you will have somebody there to help you. (Y)(52-year-old male)

\section{Conclusions and Implications}

Our focus in this chapter has been confined to lifelong residents of fishing communities in two south Louisiana coastal parishes where Katrina left a historically wide arc of destruction. Louisiana's Gulf Coast fishers and their families provide an authentic and generationally rich perspective on the experience of suffering related to natural disaster, having endured five major hurricanes in 7 years: Katrina and Rita in 2005, Gustav and Ike in 2008, and most recently, Isaac in 2012. Isaac, at first a tropical storm, then upgraded to a category 1 hurricane at landfall on August 29, 2012, was a haunting and cruel reminder of Katrina's legacy of loss, with destruction of property and homes lost once again in St. Bernard and Plaquemines Parishes. 
The three core themes presented here were based on qualitative analyses of younger and older fishers' narratives at least 5 years after Katrina. Excerpts of primary data in connection with each core theme capture the diverse concerns, challenges, and coping resources utilized to counter traumatic stress associated with what has been described at the costliest natural disaster in US history (Kessler et al., 2009). Taken together, these themes bear witness to the horror of the first days after Katrina's landfall and unprecedented flooding following levee breaches (Theme 1). The tremendous outpouring of disaster relief assistance by faith-based communities and volunteers was illuminated next (Theme 2). Within this theme, an interesting counterpoint concerned numerous reports of assistance without regard to traditional denominational boundaries, where Baptists, Amish, and many others extended a helping hand to a predominantly Catholic community of fishers. The first two themes were based on remarkably similar responses across the two age groups compared in this study. On the contrary, the last theme provided evidence of age-related differences in responses, with salient trends for younger fishers on new connections and meaningful social relationships formed with their out-of-state displacement hosts, some of which continue today. In contrast, environmental concerns were voiced more frequently by the older fishers, bringing awareness to the problem of coastal erosion and the pervasive loss of land witnessed by generations of fishing families over the past century. For both younger and older participants, realization of the importance of family ties and a strong affinity to place were unifying and salient trends.

Interviews with fishers who have endured a decade of catastrophic disasters including the recent 2010 BP oil spill (see Chap. 4, this volume) are valuable in helping psychologists, and other social services professionals appreciate the core challenges that directly affected individuals and families must face. Evidence from the clinical and public health literatures indicates that previous trauma is one of several separate risk factors for PTSD (Brewin, Andrews, \& Valentine, 2000; Tracy $\&$ Galea, 2006). Coastal fishers who have endured natural and technological disaster are at risk for adverse psychological reactions in the years after these events. In fact, over half of the fishers who participated in the present research had at least one symptom of clinical depression at the time of interview (51.6\%; Cherry et al., 2015). On the contrary, individuals and families who have experienced recurring disasters and have recovered equilibrium are a valuable resource who may illuminate keys to successful coping after disaster.

Understanding the psychological and social factors that may lessen vulnerability and promote resilience is a timely challenge given the frequency of large-scale disasters in the world today (see Chaps. 5 and 15, this volume). Our participants' responses highlight resources that seem to be facilitative in assisting recovery, as well as how and why these resources were beneficial. We received a diverse array of reports regarding how the storms influenced the fishers' relationships with friends, family, and community. Based on many reports, the people who were "there to help" and to "give you a hand up" were often from faith communities. Our findings attest to the perceived benefits of organized disaster relief efforts carried out by faith-based communities, as well as humanitarian gestures and good will extended 
by beneficent strangers, some of whom have emerged as emotionally meaningful new friends. The individual and community-wide disaster relief efforts that displaced fishers described reflect social support, consistent with a voluminous literature on perceived social support, as key for positive outcomes after disaster (Boss, 2006; Silva Brown et al., 2010; Marks, Cherry, \& Silva, 2009; Roberto, Kamo, \& Henderson, 2009; see also Chap. 10, this volume).

Scholars have made the point that disaster outcomes depend critically on a combination of risk factors and resilience characteristics (Bonnano, Brewin, Kaniasty, \& La Greca, 2010). In addition to perceived social support and reportedly closer family ties, findings from this study also highlight cultural identity as a potential resilience resource. The younger and older fishers of Isleño and Croatian descent provided novel insight into the roles cultural identity and tradition play in post-disaster recovery. The Los Isleños Museum and Village in southeastern St. Bernard and the annual fiesta to celebrate Isleños culture and heritage remind us of the longevity of commercial fishing and trapping for those whose forefathers immigrated to the Gulf Coast from the Canary Islands during the Spanish colonization of Louisiana. In Plaquemines Parish, religious observances and a special mass held in honor of St. Anthony, along with festivals and other celebrations throughout the calendar year strengthen Croatian cultural identity and ideals which include resilience and strong family ties (Ware, 1996, 2006, 2013). On a broader note, cultural identities and traditions passed down from generations of fishing families with deep roots to their coastal homes and lifestyles underscore the importance of place attachment for some, especially older fishers, and the potential for individual and community resilience despite hurricane devastation. Nonetheless, one must not forget the environmental realities of coastal erosion and the looming uncertainties associated with the BP oil spill (see Chap. 4, this volume), nor should one forget future hurricane risk in coastal communities.

In closing, our findings build on previous studies of commercial fishers and extend the literature by addressing long-term hurricane recovery in the context of exposure to an economically and environmentally devastating technological disaster (Lee \& Blanchard, 2012; see also Chap. 4, this volume). The insights and practical information that disaster survivors can provide are keys to the development of evidence-based interventions to mitigate adversity. These data show that cultural ties affect younger and older adults' coping responses and adjustment in the years after a devastating natural disaster.

Acknowledgments We are grateful to George Barisich, President of the United Commercial Fishermen's Association, for his help with recruitment and Frank Campo of Campo's Marina in Yscloskey (southeastern St. Bernard) for providing space for interviews. We thank Pam Forest Nezat, Ashley Cacamo, Annie Crapanzano, and Benjamin Staab for assistance with data collection; Trevor Johnson, Savannah Ballard, Kyle Ryker, Priscilla Lebleu, Rachel Anderson, Katie Giordano, Mallori Seeger, and Caston Montgomery for help with qualitative analyses; and Sr. Mary Keefe, Robert Campo, Lauren Denley, Huey Gonzales, Charlie Robin, John Tesvich, and Eva Vujnovich for their contributions to the research effort.

This research was supported by grants from the Louisiana Board of Regents and the BP Gulf of Mexico Research Initiative, Office of Research and Economic Development, Louisiana State University. This support is gratefully acknowledged. Correspondence concerning this article should 
be addressed to Katie E. Cherry, Department of Psychology, Louisiana State University, Baton Rouge, LA 70803-5501 (e-mail: pskatie@1su.edu).

\section{References}

Batson, M., \& Marks, L. (2008). Making the connection between prayer, faith, and forgiveness in Roman Catholic families. The Quantitative Report, 13(3), 394-415.

Bonnano, G. A., Brewin, C. R., Kaniasty, K., \& La Greca, A. M. (2010). Weighing the costs of disaster: Consequences, risks, and resilience in individuals, families, and communities. Psychological Science in the Public Interest, 11, 1-49.

Boss, P. (2006). Loss, trauma, and resilience. New York: Norton.

Brewin, C. R., Andrews, B., \& Valentine, J. D. (2000). Meta-analysis of risk factors for posttraumatic stress disorder in trauma-exposed adults. Journal of Consulting and Clinical Psychology, 68, 748-766.

Buuck, M. M. (2007). Firestorm: Hurricane Katrina and the St. Bernard Fire Department. Xlibris Corporation.

Cataldie, L. (2007). Coronor's journal: Forensics and the art of stalking death. New York: The Penguin Group (USA).

Cherry, K. E. (Ed.). (2009). Lifespan perspectives on natural disasters: Coping with Katrina, Rita and other storms. New York: Springer

Cherry, K. E., Galea, S., \& Silva, J. L. (2008). Successful aging and natural disasters: Role of adaptation and resiliency in late life. In M. Hersen \& A. M. Gross (Eds.), Handbook of clinical psychology: Volume 1 (pp. 810-833). NJ: Wiley.

Cherry, K. E., Sampson, L., Nezat, P. F., Cacamo, A., Marks, L. D., \& Galea, S. (2015). Long-term psychological outcomes in older adults after disaster: Relationships to religiosity and social support. Aging \& Mental Health, 19(5), 430-443.

Coles, F. (2012). Double identity: Isleños are Yats, too. Southern Journal of Linguistics, 36, $155-168$.

Dunn, G. E., Davis, W. R., \& Moore, P. L. (Dec, 1956). Hurricane season of 1956. Monthly Weather Review, pp. 436-443.

Faragher, J. M. (2005). A great and noble scheme: The tragic story of the expulsion of the French Acadians from their American homeland. New York: W.W. Norton.

Graumann, A., Houston, T., Lawrimore, J., Levinson, D., Lott, N., McCown, S., et al. (2005; updated 2006). Hurricane Katrina a climatological perspective: Preliminary report. Retrieved from the National Oceanic and Atmospheric Administration's National Climatic Data Center, from http://www.ncdc.noaa.gov/oa/reports/tech-report-200501z.pdf. Accessed 20 May 2013.

Janega, J. (11 Sept 2005). In some lost towns, Katrina went beyond destruction: Yscloskey, others wiped out entirely. Chicago Tribune. Retrieved from http://articles.chicagotribune.com/200509-11/news/0509110479_1_towns-parish-president-oil.

Kessler, R. C., Galea, S., Gruber, M. J., Sampson, N. A., Petukhova, M., \& Wang, P. S. (2009). Hurricane Katrina. In Y. Neria, S. Galea \& F. H. Norris (Eds.), Mental health and disasters (pp. 419-440). New York: Cambridge University Press.

Kilmer, R. P., Gil-Rivas, V., Tedeschi, R.G., \& Calhoun, L.G. (2010). Helping families and communities recover from disaster: Lessons learned from Hurricane Katrina and its aftermath. Washington, D.C.: American Psychological Association.

Lee, M. R., \& Blanchard, T. C. (2012). Community attachment and negative affective states in the context of the BP Deepwater Horizon disaster. American Behavioral Scientist, 56(1), 24-47.

Los Isleños Learn. (2014). In Bienvenido Los Islenos.org. http://www.losislenos.org/fiesta2014. html.

Louisiana Religion Traditions. (2010). http://www.thearda.com/rcms2010/r/s/22/rcms2010_22 state_adh_2010.asp. Accessed 5 Jan 2015. 
Marks, L. D., Cherry, K., \& Silva, J. (2009). Faith, crisis, coping, and meaning making after Katrina: A qualitative, cross-cohort examination. In K. Cherry (Ed.), Lifespan perspectives on natural disasters: Coping with Katrina, Rita and other storms (pp. 195-215). New York: Springer.

Moore, T. J., \& Asay, S. M. (2008). Family resource management. Thousand Oaks: Sage.

National Hurricane Center. (23 Jan 2007). November 2005 Atlantic Tropical Weather Summary. NOAA. Retrieved August 2014, from http://www.nhc.noaa.gov/archive/2005/tws/MIATWSAT_nov_final.shtml.

National Hurricane Center. (2015). http://www.nhc.noaa.gov/. Accessed 5 Jan 2015.

Neria, Y., Galea, S. \& Norris, F. H. (Eds.). (2009). Mental health and disasters. New York: Cambridge University Press.

Patton, M. Q. (2002). Qualitative research \& evaluation methods (3rd ed.). Thousand Oaks: Sage.

Roberto, K. A., Kamo, Y., \& Henderson, T. (2009). Encounters with Katrina: Dynamics of older adults' social support networks. In K. E. Cherry (Ed.), Lifespan perspectives on natural disasters: Coping with Katrina, Rita and other storms (pp. 133-152). New York: Springer.

Robin, C. J. (2000). Remedies and lost secrets of St. Bernard's Islenos. St. Bernard Village: Los Islenos Heritage and Cultural Society.

Roese, N. J., \& Olson, J. M. (2007). Better, stronger, faster self-serving judgment, affect regulation, and the optimal vigilance hypothesis. Perspectives on Psychological Science, 2, 124-141.

Schaefer, M. (2007). Lost in Katrina. Gretna: Pelican Publishing Company.

Silva Brown, J., Cherry, K. E., Marks, L. D., Volaufova, J., Lefante, C., \& Jazwinski, S. M. (2010). After Hurricanes Katrina and Rita: Gender differences in physical function and psychological well-being in middle-aged and older adults. Health Care for Women International, 31, 9971012 .

Strauss, A., \& Corbin, J. (1998). Basics of qualitative research: Techniques and procedures for developing grounded theory. Thousand Oaks: Sage.

Tracy, M., \& Galea, S. (2006). Post-traumatic stress disorder and depression among older adults after a disaster: The role of ongoing trauma and stressors. Public Policy \& Aging Report, 16(2), $16-19$.

U. S. Census Bureau. (2013). State and County Quick Facts from the U. S. Census Bureau. http:// quickfacts.census.gov/qfd/states/22000.html.

Vujnovich, M. (1974). Yugoslavs in Louisiana. Gretna: Pelican Publishing Company.

Ware, C. (1996). Croatians in southeast Louisiana: An overview. Louisiana Folklore Miscellany, $11,67-85$.

Ware, C. (2006). Croatians in Louisiana. In S. J. Bronner (Ed.), Encyclopedia of American Folklife (pp. 243-246). Armonk: M.E. Sharpe, Inc.

Ware, C. E. (2013). Louisiana's Croatian American society: A case study in adaptation and resilience. Louisiana Folklore Miscellany, 23, 97-128.

Weisler, R. H., Barbee, J. G., \& Townsend, M. H. (2006). Mental health and recovery in the Gulf Coast after Hurricanes Katrina and Rita. The Journal of the American Medical Association, 296, 585-588.

Wells, K. (2008). The good pirates of the forgotten bayous. New Haven: Yale University Press. 